\title{
First record of Parakosa flexipes (Acari: Chirodiscidae) parasitizing a free-tailed bat (Chiroptera: Molossidae) in Brazil
}

\author{
Primeiro registro de Parakosa flexipes (Acari: Chirodiscidae) parasitando um morcego-de-cauda-livre \\ (Chiroptera: Molossidae) no Brasil
}

Luiz Antonio Costa Gomes ${ }^{1 *}$; Roberta Mariano Silva²; Vanessa Lazaro Melo

${ }^{1}$ Departamento de Biologia Animal, Universidade Federal Rural do Rio de Janeiro - UFRRJ, Seropédica, RJ, Brasil

${ }^{2}$ Departamento de Ciências Biológicas, Universidade Estadual de Santa Cruz - UESC, Ilhéus, BA, Brasil

Received July 10, 2012

Accepted August 8, 2012

\begin{abstract}
The present study reports the occurrence of Parakosa flexipes (Pinichpongse) (Chirodiscidae) for the first time in Brazil, along with its infection sites on Molossus rufus E. Geoffroy. Thirty-eight bats were caught using mist nets that were placed near a house at the Mars Center for Cocoa Science in the state of Bahia, of which 14 (37\%) were parasitized by $P$. flexipes. Parakosa flexipes was observed parasitizing M. rufus on hairs that were evidently longer than others distributed over the bat's body, where up to three parasites could be spotted on a single hair.
\end{abstract}

Keywords: Mite, distribution, ectoparasite, Atlantic Forest, Molossus rufus.

\section{Resumo}

O presente estudo registra a ocorrência de Parakosa flexipes (Pinichpongse) pela primeira vez no Brasil, bem como seus sítios de infecção em Molossus rufus E. Geoffroy. Foram capturados 38 morcegos com redes-de-neblina, dispostas próximas a uma residência da "Mars Center for Cocoa Science" no Sul da Bahia, dos quais 14 (37\%) estavam parasitados por P. flexipes. Parakosa flexipes foi observada parasitando M. rufus em pelos evidentemente maiores que os demais distribuídos pelo corpo do morcego, onde se pôde observar até três parasitos em um único pelo.

Palavras-chave: Ácaro, distribuição, ectoparasita, Mata Atlântica, Molossus rufus.

Chirodiscidae (Acari: Astigmata) are characterized by having the idiosoma subcylindrical or laterally compressed and legs I and II modified to clasp the host's fur (WHITAKER JUNIOR et al., 2007). The hosts might be bats and rodents (FONSECA et al., 2005; LABRZYCKA, 2006; BOCHKOV; DUBININA, 2011). These mites are viviparous and their complete life cycle occurs on the host. It is divided between a larval stage, with hexapod larva, and an adult stage (dioecious), apart from a copulatory nymph of obscure origin (PINICHPONGSE, 1963).

Parakosa flexipes (Pinichpongse), as well as other congeners, is normally found on molossid bats (McDANIEL, 1972; GUERRERO, 1992). This mite species is different from others because of its two pairs of hairs located directly over the posterior edge of the propodosomal plate, and also because one of the tarsus IV claws is hook-shapes (CRUZ, 1969).

Molossus rufus E. Geoffroy is an insectivorous bat widely distributed in the Neotropical region (FABIAN; GREGORIN, 2007). This species is normally observed around anthropogenic constructions (PACHECO et al., 2010), and its ectoparasites

\footnotetext{
${ }^{*}$ Corresponding author: Luiz Antonio Costa Gomes

Departamento de Biologia Animal,

Universidade Federal Rural do Rio de Janeiro - UFRRJ, Seropédica, RJ, Brasil e-mail: luizantoniocg@gmail.com
}

include insects (VALIM et al., 2002; LUZ et al., 2009) and mites (PINICHPONGSE, 1963; FONSECA et al., 2005).

Mites are the least investigated bat ectoparasites in Brazil (ALMEIDA et al., 2011). The vast majority of published data available in this country is related to the order Diptera (GRACIOLLI; LINARDI, 2002; GRACIOLLI; BIANCONI, 2007; SANTOS et al., 2009). Thus, the present study had the aim of reporting the first occurrence of a chirodiscid mite in molossid bats in Brazil, determining infection sites on the host.

This study was conducted at the Mars Center for Cocoa Science (MCCS; $14^{\circ} 43^{\prime} 02^{\prime \prime} \mathrm{S}$ and $39^{\circ} 22^{\prime} 06^{\prime \prime} \mathrm{W}$ ), which is located in the municipality of Barro Preto, in the southern region of the state of Bahia, Brazil, at an altitude of 71 meters. The MCCS is located in the Atlantic Forest biome and is a farm that focuses on research and plantation cocoa trees and some intercrops that grow with these plants (banana and palm trees).

A colony of $M$. rufus was found in a site of $80 \mathrm{~m}^{2}$ between a ceiling liner and the roof of a house at the MCCS. Three campaigns were conducted during March 2011, in which specimens were caught using two mist nets ( 12 per $2.5 \mathrm{~m}$ ) that had been placed near a hole that gave access to the ceiling liner of the house. The bats were caught under a license granted by the Brazilian environmental control agency (SISBIO/ICMBIO, \# 28638-1). 
The mites were stored in Eppendorf tubes filled with 70\% alcohol solution and later on were mounted on microscope slides (FLECHTMANN, 1990), been identified in accordance with the identification key of Guerrero (1992). The mites were deposited in the reference collection of the Tick Morphophysiology and Ixodology Laboratory of the Federal Rural University of Rio de Janeiro, Seropédica, RJ. The sites where the ectoparasites were captured on the host were recorded. The bat specimens can be found in the Alexandre Rodrigues Ferreira Mammal Collection, Santa Cruz State University, Ilhéus, BA.

This is the first study to record occurrences of Parakosa McDaniel \& Lawrence parasitizing $M$. rufus in Brazil, and the fifth to record the family Chirodiscidae parasitizing bats in this country. The first and second records were made by Fain (1973) (FAIN, 1976 apud GUERRERO, 1992), who found Paralabidocarpus tonatiae Fain parasitizing Sturnira lilium (E. Geoffroy) in Amazonas and Labidocarpellus chrotopterus Fain parasitizing Chrotopterus auritus Peters in Santa Catarina States. The third record was made by Azevedo et al. (2002), who recorded Paralabidocarpus sp. parasitizing Phyllostomus hastatus Pallas in Minas Gerais State. The most recent account of this family was provided by Fonseca et al. (2005), who observed Dentocarpus silvai silvai Dusbabek and Cruz parasitizing Molossus molossus (Pallas) and M. rufus in the state of Rio de Janeiro.

Fourteen (37\%) M. rufus specimens, all females, were observed to be parasitized by $P$. flexipes out of the total of 38 bats analyzed. Among the mites caught there were six free larvae, a copulatory nymph, six adult males and five adult females, two of which containing visible larvae inside their idiosoma (Figure 1). The larvae inside the females' idiosoma showed the gnathosoma arranged to the posterior side, as observed by Fonseca et al. (2005) in D. silvai silvai, which corroborates the hypothesis of viviparity among chirodiscid mites (GUERRERO, 1992). For five mites, the development stage could not be identified because of damage that occurred during the bleaching process.

Four M. molossus bats (Molossidae) and one Myotis sp. (Vespertilionidae) were also observed cohabiting with $M$. rufus in the same ceiling liner, but were not parasitized. Interspecies cohabitation between bats may occur without interaction between the species. However, this interaction might be more intimate during non-reproductive periods (KUNZ, 1982) or in small shelters with only one access (COSTA et al., 2010).

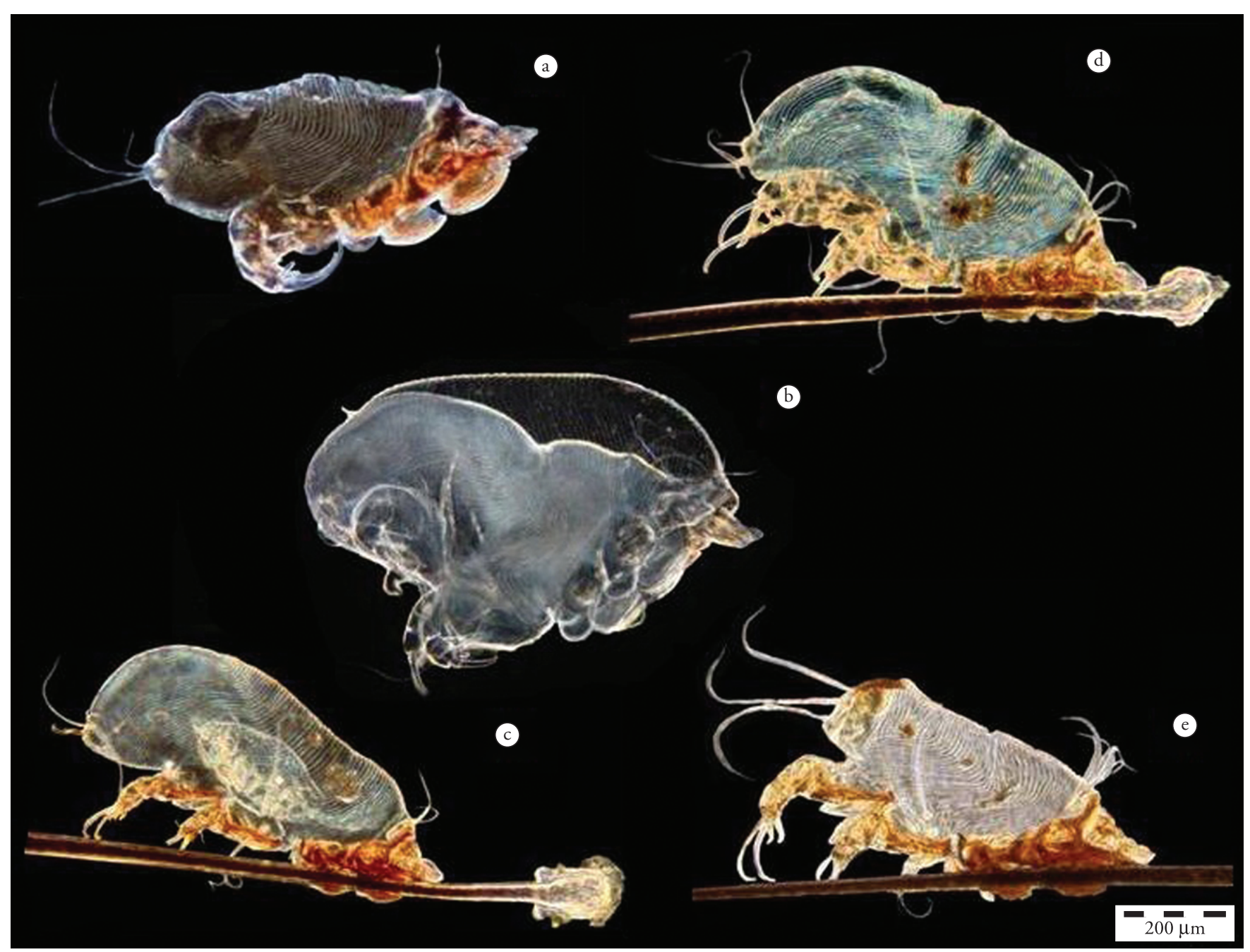

Figure 1. Development stages of Parakosa flexipes: a) free larva; b) copulatory nymph; c) female adult with larva in its interior; d) female adult; and e) male adult. Photos: Vinícius da Rocha Miranda. 
Parakosa flexipes was observed parasitizing $M$. rufus on hairs that were evidently longer than others, distributed over the bat's body, where up to three parasites could be spotted on a single hair. These hairs were found on the dorsal extremity with an approximate distance of three centimeters from the uropatagium on the right and/or left side of the host. Dusbabek \& Cruz (1966) also observed P. flexipes parasitizing long hairs between the uropatagium and the dorsal part of the body of $M$. molossus in Cuba. According analysis realized by Labrzycka (2006) about morphology and biological adaptation of fur mites in Poland, it was also observed that chirodiscids are commonly found on the hair of the posterior area of bats and rarely on the head or near the ears. Remaining on the longer hairs located on the bats' back may be a way in which the parasites avoid removal through licking, as a cleaning method used by the hosts (FONSECA et al., 2005). These hairs are thicker than the others, thus allowing better lift provided by the two pairs of legs that are modified to clasp the host's hair. Characteristics such as the thickness and texture of the fur, as well as differences between the skin secretion levels in certain parts of the host's body, might have an influence on the choice of microhabitat (FAIN; LUKOSCHUS, 1985).

These data extend the geographical distribution of the genus Parakosa and the species $P$. flexipes to one more country. One reason for the scarceness of studies about chirodiscid ectoparasites may be the fact that the dimensions of these parasites are measured in millimeters and, thus, they are often not perceived by the researchers in the field, which precludes their capture. Detailed verification of the bats' fur, focusing on the hosts' long dorsal hair could increase the records of $P$. flexipes and even of other species of the family Chirodiscidae in Brazil.

\section{Acknowledgements}

To Michel Paiva Valim for identifying the mites to genus level; to Solange Viana Paschoal Blanco Brandolini and Gledson Vigiano Bianconi for reviewing the manuscript; to Kátia Maria Famadas and Elizabete Captivo Lourenço for their logistic support in mounting the ectoparasites; and to the Mars Center for Cocoa Science for the capture permit and logistic support.

\section{References}

Almeida JC, Silva SSP, Serra-Freire NM, Valim MP. Ectoparasites (Insecta and Acari) associated with bats in Southeastern Brazil. J Med Entomol 2011; 48: 753-757. PMid:21845932. http://dx.doi. org/10.1603/ME09133

Azevedo AA, Linardi PM, Coutinho MTZ. Acari ectoparasites of bats from Minas Gerais, Brazil. J Med Entomol 2002; 39(3): 553-555. PMid:12061455. http://dx.doi.org/10.1603/0022-2585-39.3.553

Bochkov AV, Dubinina HV. Mites of the genus Schizocarpus (Acariformes: Chirodiscidae) parasitizing the eurasian beaver Castor fiber (Rodentia: Castoridae) in the Voronezh National Reserve. Acarina 2011; 19(1): 53-66.

Costa LM, Lourenço EC, Esbérard CEL, Silva RM. Colony size, sex ratio and cohabitation in roosts of Phyllostomus hastatus (Pallas) (Chiroptera:
Phyllostomidae). BrazJ Biol2010; 70(4): 1047-1053. PMid:21180912. http://dx.doi.org/10.1590/S1519-69842010000500019

Cruz J. Nueva especie de acaro (Acarina: Listrophoridae) parasito de murciélagos cubanos. Poeyana Ser A 1969; 62: 1-8.

Dusbabek F, Cruz J. Nuevos géneros y especies de acaros (Acarina: Listrophoridae) parásitos de murciélagos cubanos. Poeyana Ser A 1966; 31: 1-20.

Fabian ME, Gregorin R. Família Molossidae. In: Reis NR, Peracchi AL, Pedro WA, Lima IP. Morcegos do Brasil. Londrina: Universidade Estadual de Londrina; 2007. p. 149-165.

Fain, A. Les Listrophoridés d'Amérique néotropicale (Acarina: Sarcoptiformes) I. Familles Listrophoridae et Chirodiscidae. Bull Inst $R$ Sci Nat Belg Entomol 1973; 49:1-149.

Fain A, Lukoschus F. The genus Schizocarpus Trouessart, 1896 (Acari, Chirodiscidae) from the beaver Castor fiber L.: an exemple of multiple speciation. Entomol Abh 1985; 49:35-68.

Flechtmann CHW. Ácaros de Importância Médico Veterinária. São Paulo: Editora Nobel; 1990.

Fonseca MA, Valim MP, Botão-Miranda RA, Gitti CB, Amorin, M, Serra-Freire NM. Ocorrência de Dentocarpus silvai silvai Dusbabek \& Cruz, 1966 (Acari: Chirodiscidae) em duas espécies de molossídeos (Mammalia: Chiroptera) no Estado do Rio de Janeiro, Brasil. Entomol Vect 2005; 12(1): 117-121. http://dx.doi.org/10.1590/ S0328-03812005000100010

Graciolli G, Linardi PM. Some Streblidae and Nycteribiidae (Diptera: Hippoboscoidea) from Maracá Island, Roraima, Brazil. Mem Inst Oswaldo Cruz 2002; 97(1): 139-141. PMid:11992166. http://dx.doi. org/10.1590/S0074-02762002000100026

Graciolli G, Bianconi GV. Moscas ectoparasitas (Diptera, Streblidae, Nycteribiidae) em morcegos (Mammalia, Chiroptera) em área com Floresta de Araucária no Estado do Paraná, sul do Brasil. Rev Bras Zool 2007; 24(1): 246-249. http://dx.doi.org/10.1590/ S0101-81752007000100033

Guerrero R. Catálago de los Labidocarpidae (Acarina: Listrophoroidea) parásitos de los murciélagos (Mammalia, Chiroptera) neotropicales. Stud Neotrop Fauna Environ 1992; 27(1): 19-41. http://dx.doi. org/10.1080/01650529209360864

Kunz TH. Roost ecology of bats. In: Kunz TH. Ecology of bats. New York: Plenum Press; 1982. p. 1-55. PMid:7061994. http://dx.doi. org/10.1007/978-1-4613-3421-7_1

Labrzycka A. A perfect clasp - adaptation of mites to parasitize mammalian fur. Biol Lett 2006; 43(2): 109-118.

Luz JL, Costa LM, Gomes LAC, Esbérard CEL. The chiggerflea Hectopsylla pulex (Siphonaptera: Tungidae) as an ectoparasite of free-tailed bats (Chiroptera: Molossidae). Mem Inst Oswaldo Cruz 2009; 104(4): 567-569. PMid:19722077. http://dx.doi. org/10.1590/S0074-02762009000400005

McDaniel B. Labidocarpid bat-mites of Venezuela (Listrophoroidea: Labidocarpidae). Brigham Young Univ Sci Bull Biol Ser 1972; 17(2): 15-32.

Pacheco SM, Sodré M, Gama AR, Bredt A, Cavallini-Sanches EM, Marques RV, et al. Morcegos urbanos: status do conhecimento e plano de ação para a conservação no Brasil. Chiropt Neotrop 2010; 16(1): 629-647.

Pinichpongse S. A review of the Chirodiscinae with descriptions of new taxa (Acarina: Listrophoridae) (Part three). Acarologia 1963; 5(3): 397-404. 
Santos CLC, Dias PA, Rodrigues FS, Lobato KS, Rosa LC, Oliveira TG, et al. Moscas ectoparasitas (Diptera: Streblidae) de morcegos (Mammalia: Chiroptera) do Município de São Luís, MA: taxas de infestação e associações parasito-hospedeiro. Neotrop Entomol 2009; 38(5): 595-601. PMid:19943006. http://dx.doi. org/10.1590/S1519-566X2009000500006

Valim MP, Botão-Miranda RA, Gitti CB, Amorim M, Serra-Freire NM. Ocorrência de Hesperoctenes hermsl Ferris \& Usinger, 1939 (Hemiptera:
Polyctenidae) parasitando Molossus ater Geoffroy, 1805(Chiroptera: Molossidae) em Silva Jardim, Estado do Rio de Janeiro, Brasil. Entomol Vectores 2002; 9(3): 359-364.

Whitaker Junior JO, Walters BL, Castor LK, Ritzi CM, Wilson N. Host and distribution lists of mites (Acari), parasitic and phoretic, in the hair or on the skin of North American wild mammals north of Mexico: records since 1974. Lincoln: Faculty Publications from the Harold W. Manter Laboratory of Parasitology, University of Nebraska; 2007. 